\title{
Nano-Emptiness Space of Oil-Bearing Rocks
}

\author{
Osovetsky B* \\ Nanomineralogy Sector, Perm State National Research University, Russia
}

Submission: April 17, 2017; Published: April 26, 2017

*Corresponding author: Boris Osovetsky, Nanomineralogy Sector, Perm State National Research University, Perm, Bukirev st 15, Russia, Email: opal@psu.ru

\section{Introduction}

The electron microscopic and X-ray tomography studies of oil-bearing rocks showed a great variety and wide volume limits of an emptiness space. It includes macro- and with the corresponding micro-fragments of space closely connected each other. Micro-emptiness space predominates in volume in thin-grained terrigenous rocks, especially in argillites. But even in carbonate rocks it plays very important role as system of canals for oil migration.

Micro-emptiness space is composed by micro-cracks, micro-pores, and micro-cavities, as well as intermediate and transitional morphological types. The nature of the microemptiness space (structure, volume, filling in organic or mineral matter, etc.) determines many properties of reservoir rocks and their oil saturation. Its study is carried out by many methods, and it is very useful for sorting out the geophysical information used in the correlation of oil-bearing strata sections.

This short communication devoted to the problems of emptiness space study under a high-resolution scanning electron microscope. The objects of the author's investigation were some oil deposits of the Perm Region, Russia. The methods of high-resolution electron microscopy were applied to study the nano-sized fragments of rock emptiness space. The polished sections of terrigenous and carbonate rocks were studied under JSM 7500F (Jeol) microscope with cool emission. The regime for standard scanning electron image for analysis was acceleration voltage of $15 \mathrm{kV}$, emission current of $10 \mu \mathrm{A}$, work distance of $8 \mathrm{~mm}$.

The use of high-resolution electron microscopy methods has shown that the micro-emptiness space of reservoir rocks is practically inextricably linked with the nano-emptiness one. The main structural fragments of the nano-emptiness space are nano-cracks and nano-pores, which directly contacted with the corresponding micro-fragments. The wide spread of nano-cracks is due to the fact that virtually every micro-crack before the wedging along the strike and into the depth turns into nano-tracks, the extent of which can significantly exceed that of the mother micro-crack. Besides, many micro-cracks narrow up to nano-sized width in definite their parts (Figure 1).

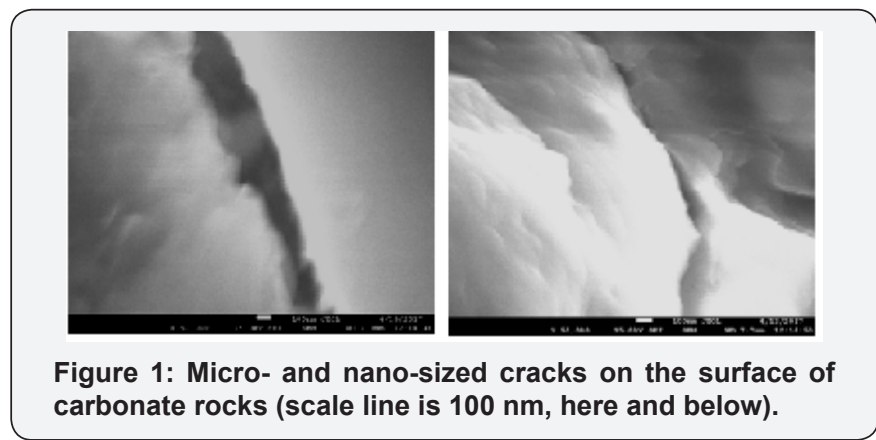

Accordingly, the study of micro-pores under an electron microscope with high resolution shows that they gradually narrow to the depth, and several deeper canals of nano-scale width usually remain at the bottom (Figure 2).

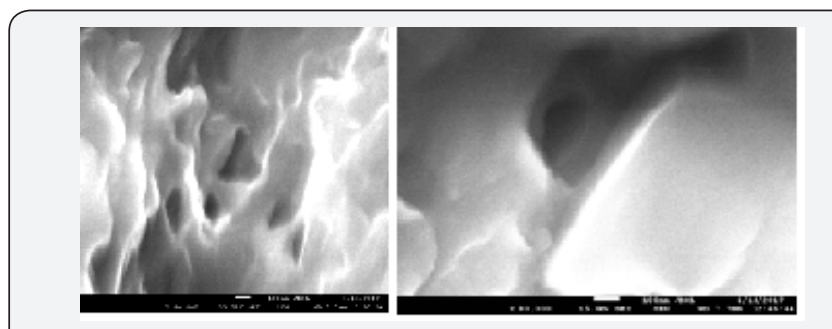

Figure 2: Micro- and nano-pores on the surface of argillites.

Besides the common joint systems of micro- and nanodefects, there are the separate analogous nano-systems. Presumably, they fix the places of weak influences of external factors: tectonic and catagenesis processes, interstitial solution, etc.

At present, the share of the nano-emptiness space in the total volume of reservoir rock can be estimated only very approximately, and the oil industry does not particularly interest this task in connection with the impossibility of oil migration through the nano-canals. However, in some cases nano-space can play a significant role. As an example we may discuss on thin-layered argillites. 
The nano-emptiness space in argillites is the important component of their structure, and its transformation may remarkably influence on oil migration. Note that a significant part of the basic mineral matter of argillites (montmorillonite, hydromica, and kaolinite) in particle size refers to the nanoscale range if we take into account the thickness of flakes. They can largely fill the nano-cracks, and gradually expand them due to the swelling of montmorillonite packets.

In some argillaceous strata the extensive systems of crossing and interlayer micro-cracks have been forming during the stage of catagenesis. It is assumed that many of them pass into nano-cracks in separate segments and when they are wedged out. This factor may be disregarded. However, the abundance of micro- and nano-cracks leads to a noticeable change in the petro-physical properties of the reservoir rocks, which must be taken into account in the correlation of the strata. In addition, such rock behaves differently under the drilling process.

This work is licensed under Creative Commons Attribution 4.0 Licens

DOI: $10.19080 /$ RAPSCI.2017.01.555556
The processes in the nano-emptiness space should be examined when assessing the effect of drilling fluids on oil reservoirs. In particular, the precipitation of salt nano-crystals constantly occurs from these solutions. They arbitrarily fill the micro- and especially the nano-emptiness space. In the future, salt nano-crystals begin to grow and, due to the crystallization force, they make significant changes in the structure of the reservoir rocks (such as expansion and elongation of cracks and pores). These transformations lead to the appearance of the secondary emptiness space of another nature.

The processes that take place in the reservoir are also directly related to the structure of the nano-emptiness space when solving the problems of increasing of oil recovery from thin-grained rocks. Many of them require special consideration from theoretical positions and by setting appropriate experiments.

\section{Your next submission with Juniper Publishers} will reach you the below assets

- Quality Editorial service

- Swift Peer Review

- Reprints availability

- E-prints Service

- Manuscript Podcast for convenient understanding

- Global attainment for your research

- Manuscript accessibility in different formats

( Pdf, E-pub, Full Text, Audio)

- Unceasing customer service

Track the below URL for one-step submission https://juniperpublishers.com/online-submission.php 